\title{
Self-efficacy, Personal Worries, and School Achievement of Primary School Students in Hong Kong
}

\author{
Nancy Cheng \\ Methodist School, Kowloon, Hong Kong \\ Peter Westwood \\ Education Consultant, Macau, China
}

\begin{abstract}
This article reports data from 154 primary-school children attending a government school in Hong Kong. Focus group discussions and a questionnaire were used to gain information on children's worries within the school context and in their lives outside school. Data were also collected on children's perceived self-efficacy across academic and non-academic domains. The study explored the nature of children's personal worries and the relationships existing among variables comprising degree of worry, self-efficacy, and academic achievement.
\end{abstract}

An interesting area of research that has evolved over the past sixty years has focused on children's worries (e.g. Brimacombe, 1985; Christie \& MacMullin, 1998; Kong, Westwood \& Yuen, 2006; Simon \& Ward, 1974; Vasey \& Daleiden, 1994; Zeligs, 1939). Results have indicated that children do worry - sometimes intensely and frequently - about a wide range of issues. A study in the US involving children in Grades 2 to 6 discovered that they worried most about healthrelated matters (operations, medical treatment, getting sick, the health of family members), school issues (tests and grades, being called on to perform), and the possibility of personal harm (being physically attacked and hurt by others) (Silverman, La Greca \& Wasserstein, 1995). Another study in the US reported that both male and female students in the age range 8 to 11 years rated 'getting poor grades' and 'failing a test' among their top worries, although not higher than worries related to physical danger (Ollendick,
1983). Similar studies in The Netherlands and Belgium have reported that almost $70 \%$ of a group of normal 8 to 12 year-old children expressed worries concerning school performance, health, and social relationships (Muris, Meesters, Merckelbach, Sermon \& Zwakhalen, 1998), while a survey of Tanzanian children identified their worries as falling into the categories of education, health, and safety (Snipstad, Lie \& Winje, 2005). An Australian study involving primary school children found that worries about school matters, such as keeping up with the workload, meeting deadlines, and doing well in tests, ranked highest out of 31 possible sources of worry in both frequency of occurrence and in intensity (Christie \& MacMullin, 1998). Several recent studies involving secondary school students in Hong Kong have identified school examinations, workload, and homework as the principal causes of worry, contributing significantly to students' stress levels (Hui, 2001; Kong et al., 2006; Li \& Ng, 1992). 


\section{The potential impact of worrying thoughts}

Teachers, school counselors, and parents need to be alert to the fact that children may, from time to time, experience significant degrees of worry, because worrying can impair a child's academic progress as well as cause problems in social and emotional adjustment (McGuigan, 1999). Frequent worrying disrupts effective learning by interfering with the individual's ability to concentrate appropriately on learning tasks (Klinger, 1999; Rapee, 1991). Intense worrying can also cause emotional stress, sleep disturbance, depression, psychosomatic illnesses, and absenteeism (Winkley, 1996; Woolcock \& Campbell, 2005). Excessive worry is 'maladaptive' in the sense that the worrier tends to go over and over the same problem or issue without necessarily achieving a solution or closure (Vasey \& Daleiden, 1994). It is the intrusive nature of worrying that represents its most salient feature (Roemer \& Borkovec, 1993; Silverman et al., 1995).

On the positive side, it has been suggested by some writers that a small degree of worry appears to be beneficial in helping a person prepare for a particular situation, such as taking a test or being interviewed. Some components of worry appear to have a positive proactive function in that they enable an individual to anticipate and solve real or potential problems ahead of time and thus avoid difficulties (Mathews, 1990). But too much worrying can be detrimental because it impairs the ability to concentrate and to work efficiently (Barlow, 1991; DeCatanzaro, 1999).

\section{Self-efficacy and worrying}

In 1960, Sarason, Davidson, Lighthall, Waite $\&$ Ruebush reviewed the existing research on childhood worries and concluded that worrying is directly associated with children's anxiety about their own self-efficacy (personal adequacy) in various situations. Self-efficacy can be defined as the personal beliefs an individual develops about his or her own competence to deal with challenges and responsibilities faced in everyday life (Bandura, 1999; Maddux \& Gosselin, 2003).
Students who doubt their own self-efficacy have many things to worry about, both inside and outside school.

It could be hypothesized that there may be an inverse relationship between students' perceived self-efficacy and their tendency to worry; and that low self-efficacy and excessive worrying may both impact negatively upon school achievement. If a student does not feel potentially effective when contemplating curricular challenges in school, he or she may worry to a much greater degree than do the students who hold positive self-efficacy beliefs.

It could be further hypothesized that because success and failure in school strongly influence the development of self-efficacy beliefs - at least in relation to coping with schoolwork (Bandura, 1997; Smith, Wakely, De Kruif \& Swartz., 2003) - there may be a significant difference between highachieving and low-achieving students in their perceived self-efficacy and their degree of worrying. Schunk and Pajares (2002) have pointed out that, compared with students who doubt their learning capabilities, those who feel efficacious for learning participate more readily work harder and persist longer when they encounter difficulties, and achieve at a higher level. Students who are not achieving well in school have their self-efficacy beliefs constantly weakened when they see other students being more successful.

\section{Purpose of the study}

The study reported here was designed to investigate the nature of the worries experienced by a sample of children from grades Primary 3 (P3), age range 8 to 9 years, and Primary 6 (P6), age range 11 to 12 years, in a co-educational primary school in Hong Kong, and to relate their degree of worrying to measures of their self-efficacy and academic achievement. The focus of attention was not restricted to school-related worries such as study load, homework and examinations, but included consideration of other potential sources of concern in life outside school. The study was also designed to identify any differences in self- 
efficacy and degree of worrying between highachieving and low-achieving students.

The specific research questions addressed in the study were:

1. What are the issues and topics about which primary school children in Hong Kong worry?

2. Is there a difference between higherachieving and lower-achieving children in the issues that cause them serious worry?

3. Do the children in this study hold positive beliefs concerning their own self-efficacy in a variety of situations?

4. Is there a difference between higherachieving and lower-achieving children in terms of perceived self-efficacy?

5. Do significant associations exist between primary school children's level of selfefficacy, academic achievement level, and the degree to which they worry?

\section{METHOD}

\section{Participants}

The study was conducted with 154 children (76 males, 78 females) from a co-educational government-aided primary school in the Kowloon District of Hong Kong. Parental written consent had been obtained to allow children to participate in the study. The children were assured that their responses were confidential and they would not be named later in any documents. They were also told that they could withdraw from the study at any time.

The participants came from P3 $(n=73)$ and P6 $(n=81)$ and covered the normal range of ability from high achievers to low achievers. The group did not contain any children assessed as having special educational needs.

\section{Instruments}

\section{Student Worries Scale (SWS)}

This 20-item scale was constructed specifically for this study using a research method recommended by Christie and MacMullin (1998). The children's worries were first identified during a focus group meeting held prior to the main survey, as described more fully below. The worries listed by the children were later analyzed into two categories: (i) worries related to school (ii) worries related to life outside school. From the large pool of listed worries the most frequently mentioned 20 issues were selected to form the key items in the $S W S$ questionnaire. The questionnaire format presented a series of personal statements (e.g. "I am worried about having too much homework") with which each participant registered a degree of agreement or disagreement using a 4-point rating scale where 4 represented 'strong agreement.' The items in Table 1 indicate clearly what the children were asked. The instrument was presented in Chinese, but has been translated into English for the purposes of this paper. Internal consistency (Cronbach alpha) of SWS was found to be .82 .

\section{Self-Efficacy Scale (SES)}

A questionnaire containing 24 items related to children's general self-efficacy was adapted for this study from the existing Academic and NonAcademic Self-Efficacy Scale (ANASS) designed by Yuen, Westwood, and Wong (2006). The questionnaire comprised a series of statements such as "How good are you at learning computer skills?" each followed by a Likert-type 4-point rating scale where 4 represented 'very competent.' Initially it was thought that the instrument had a simple underlying structure, with one set of items relating to academic efficacy together with another set covering nonacademic competencies. However, subsequent factor analysis of $S E S$ revealed 6 factors with eigenvalues greater than 1.0, accounting for 55\% of the total variance in scores. The SES was presented to the children in Chinese but has been translated into English for the purposes of this paper. The items in Table 2 clearly indicate what was asked in the self-efficacy questionnaire. Internal consistency of the instrument (Cronbach alpha) was found to be .85 . 
In order to check readability and clarity of the Chinese language version of the two questionnaires, they were administered to a small group of children not involved in the main study. As a result, some very minor adjustments were made to wording and format.

\section{Academic Achievement}

Children's academic achievement levels were determined from classroom weekly test results obtained from teachers' records. The test results were summed and converted to a percentage figure for each child.

\section{Procedure}

\section{Stage 1: Focus group meeting}

Four children from P3 and 4 from P6 were chosen to take part in a preliminary group meeting conducted by the principal investigator (Cheng). After some general introductory discussion, the children were asked to write down details of any worries, concerns or anxieties they or their friends had experienced recently. They were guided to think not only of school-related issues but also family, personal, and other possible worries. Following the meeting, the information provided by the children was analysed, categorized, and used to create the 20-item Student Worries Scale (SWS) described above.

\section{Stage 2: Main survey}

The 154 children who volunteered to participate in the main survey were placed in groups and completed the $S W S$ questionnaire under supervision during various lunchtimes, in quiet classrooms assigned for the purpose. To ensure that all participants understood the material, the researcher read aloud each question before the children responded individually on their sheets. All participants then completed the SES questionnaire under the same conditions. The children were told not to identify themselves on the questionnaire pages, and they were reassured that their responses would remain anonymous.

\section{Analysis of data}

The data were processed using SPSS for Windows to produce descriptive statistics (means and standard deviations), to calculate Pearson product-moment correlations, and to conduct ' $\mathrm{t}$ ' tests. A significance level of $\mathrm{p}<.05$ was adopted as the criterion in all ' $t$ ' testing. A significance level of $\mathrm{p}<.01$ was adopted for correlation coefficients.

\section{RESULTS}

Table 1 summarizes information relevant to answering research questions 1 and 2. Column A reports the means and standard deviations for all children in the sample. Columns B and C report separately the means and standard deviations for lower-achieving and higher-achieving children. For purposes of convenient interpretation, mean ratings above 2.5 (on the 4-point scale) were taken to indicate a tendency to worry about a particular issue. A mean rating above 3.0 suggested moderate to high degree of worry. A mean rating below 1.9 was taken to indicate that the issue was not a major source of worry for most children in this study.

Using the stated criteria, it is clear from the data in column A that children's mean scores were above 2.5 in a total of 7 items (35\%). However, in only 1 of these items did the mean rating score exceed 3.0, suggesting that the children in this study do have worries, but the intensity of their worrying tends to be moderate, rather than high. Children's most significant worries centered on family and health issues and on the implications of getting poor tests results in school. The majority of children appeared least worried about their pocket money situation, being allowed to buy things they want, and the general difficulty level of schoolwork (although on this last issue, lower-achieving children expressed greater concern than the higherachievers).

When the responses of boys were compared with those of girls, only one significant difference was detected. Girls recorded a significantly higher 
Table 1.

Worries of primary school children: Whole sample, lower achievers, and higher achievers.

\begin{tabular}{|c|c|c|c|c|c|c|c|}
\hline $\begin{array}{l}\text { Item } \\
\text { I worry about... }\end{array}$ & $\begin{array}{c}\text { A } \\
\text { All } \\
\text { Students } \\
\text { Mean } \\
(\mathrm{SD}) \\
\mathrm{n}=154\end{array}$ & $\begin{array}{c}\text { B } \\
\text { Lower } \\
\text { Achievers } \\
\text { Mean } \\
(\mathrm{SD}) \\
\mathrm{n}=31\end{array}$ & $\begin{array}{c}\text { C } \\
\text { Higher } \\
\text { Achievers } \\
\text { Mean } \\
\text { (SD) } \\
\mathrm{n}=30\end{array}$ & $\begin{array}{l}\text { Diff } \\
\text { B - C }\end{array}$ & df & $t$ & $p$ \\
\hline The health of my family members & $\begin{array}{l}3.05 \\
(1.02)\end{array}$ & $\begin{array}{l}3.08 \\
(1.00)\end{array}$ & $\begin{array}{l}3.03 \\
(1.01)\end{array}$ & 0.05 & 75 & 0.23 & .82 \\
\hline My own health & $\begin{array}{l}2.88 \\
(1.15)\end{array}$ & $\begin{array}{l}3.13 \\
(1.14)\end{array}$ & $\begin{array}{l}3.05 \\
(1.08)\end{array}$ & 0.08 & 75 & 0.32 & .75 \\
\hline My parents may lose their jobs & $\begin{array}{l}2.86 \\
(1.20)\end{array}$ & $\begin{array}{l}3.08 \\
(1.17)\end{array}$ & $\begin{array}{l}2.72 \\
(1.17)\end{array}$ & 0.36 & 75 & 1.35 & .18 \\
\hline $\begin{array}{l}\text { I may not go to a good secondary } \\
\text { school }\end{array}$ & $\begin{array}{l}2.74 \\
(1.11)\end{array}$ & $\begin{array}{l}3.03 \\
(1.08)\end{array}$ & $\begin{array}{l}2.36 \\
(1.16)\end{array}$ & 0.67 & 75 & 2.62 & .01 \\
\hline Getting poor results in tests & $\begin{array}{l}2.68 \\
(1.03)\end{array}$ & $\begin{array}{l}3.21 \\
(0.78)\end{array}$ & $\begin{array}{l}2.21 \\
(1.08)\end{array}$ & 1.00 & 69 & 4.70 & .00 \\
\hline Failing important examinations & $\begin{array}{l}2.60 \\
(1.18)\end{array}$ & $\begin{array}{l}3.32 \\
(0.91)\end{array}$ & $\begin{array}{l}1.82 \\
(1.12)\end{array}$ & 1.50 & 69 & 6.73 & .00 \\
\hline My parents will scold me & $\begin{array}{l}2.49 \\
(1.02)\end{array}$ & $\begin{array}{l}2.24 \\
(1.00)\end{array}$ & $\begin{array}{l}2.36 \\
(0.96)\end{array}$ & 0.12 & 75 & 0.55 & .59 \\
\hline My teacher will scold me & $\begin{array}{l}2.35 \\
(1.03)\end{array}$ & $\begin{array}{l}2.47 \\
(1.11)\end{array}$ & $\begin{array}{l}2.23 \\
(0.96)\end{array}$ & 0.24 & 75 & 1.03 & .31 \\
\hline $\begin{array}{l}\text { Keeping good relationships with my } \\
\text { friends }\end{array}$ & $\begin{array}{l}2.19 \\
(1.12)\end{array}$ & $\begin{array}{l}2.26 \\
(1.06)\end{array}$ & $\begin{array}{l}2.18 \\
(1.14)\end{array}$ & 0.08 & 75 & 0.33 & .74 \\
\hline $\begin{array}{l}\text { Not having enough time to eat food } \\
\text { at recess }\end{array}$ & $\begin{array}{l}2.16 \\
(1.23) \\
\end{array}$ & $\begin{array}{l}2.29 \\
(1.25) \\
\end{array}$ & $\begin{array}{l}1.92 \\
(1.18) \\
\end{array}$ & 0.37 & 75 & 1.32 & .19 \\
\hline Being teased or talked about & $\begin{array}{l}2.14 \\
(1.10)\end{array}$ & $\begin{array}{l}2.53 \\
(1.11) \\
\end{array}$ & $\begin{array}{l}1.74 \\
(0.94)\end{array}$ & 0.79 & 75 & 3.35 & .00 \\
\hline $\begin{array}{l}\text { Teachers having bad impression of } \\
\text { me if I hand my work in late }\end{array}$ & $\begin{array}{l}2.06 \\
(1.07)\end{array}$ & $\begin{array}{l}1.97 \\
(1.05)\end{array}$ & $\begin{array}{l}1.90 \\
(1.05)\end{array}$ & 0.07 & 75 & 0.32 & .75 \\
\hline $\begin{array}{l}\text { My work not meeting teacher's } \\
\text { expectation }\end{array}$ & $\begin{array}{l}2.01 \\
(0.99)\end{array}$ & $\begin{array}{l}2.34 \\
(0.91)\end{array}$ & $\begin{array}{l}1.72 \\
(0.97)\end{array}$ & 0.62 & 75 & 2.91 & .01 \\
\hline My personal appearance & $\begin{array}{l}2.01 \\
(1.06) \\
\end{array}$ & $\begin{array}{l}2.45 \\
(1.13) \\
\end{array}$ & $\begin{array}{l}1.67 \\
(0.81) \\
\end{array}$ & 0.78 & 67 & 3.48 & .00 \\
\hline Not coming top in the class & $\begin{array}{l}2.00 \\
(1.12)\end{array}$ & $\begin{array}{l}2.16 \\
(1.22)\end{array}$ & $\begin{array}{l}1.82 \\
(0.94)\end{array}$ & 0.34 & 69 & 1.36 & .18 \\
\hline $\begin{array}{l}\text { Not doing well in extra-curricular } \\
\text { activities }\end{array}$ & $\begin{array}{l}1.99 \\
(1.03)\end{array}$ & $\begin{array}{l}1.92 \\
(1.00)\end{array}$ & $\begin{array}{l}2.05 \\
(1.02) \\
\end{array}$ & 0.13 & 75 & 0.57 & .57 \\
\hline Too much homework & $\begin{array}{l}1.92 \\
(1.04)\end{array}$ & $\begin{array}{l}2.11 \\
(1.13)\end{array}$ & $\begin{array}{l}1.74 \\
(1.02)\end{array}$ & 0.37 & 75 & 1.47 & .15 \\
\hline $\begin{array}{l}\text { Not being allowed to buy what I } \\
\text { want }\end{array}$ & $\begin{array}{l}1.84 \\
(0.95)\end{array}$ & $\begin{array}{l}1.84 \\
(0.86)\end{array}$ & $\begin{array}{l}1.59 \\
(0.82)\end{array}$ & 0.25 & 75 & 1.32 & .19 \\
\hline $\begin{array}{l}\text { School work being too difficult for } \\
\text { me }\end{array}$ & $\begin{array}{l}1.83 \\
(0.96)\end{array}$ & $\begin{array}{l}\mathbf{2 . 0 8} \\
(\mathbf{1 . 1 2})\end{array}$ & $\begin{array}{l}1.26 \\
(0.50)\end{array}$ & 0.82 & 51 & 4.13 & .00 \\
\hline Not having enough pocket money & $\begin{array}{l}1.61 \\
(0.97)\end{array}$ & $\begin{array}{l}1.79 \\
(1.06)\end{array}$ & $\begin{array}{l}1.41 \\
(0.85)\end{array}$ & 0.38 & 75 & 1.72 & .09 \\
\hline
\end{tabular}


Table 2.

Self-efficacy: Whole sample, lower achievers, and higher achievers

\begin{tabular}{|c|c|c|c|c|c|c|c|}
\hline $\begin{array}{l}\text { Item } \\
\text { How good are you at ...? }\end{array}$ & $\begin{array}{c}\text { A } \\
\text { All } \\
\text { Students } \\
\text { Mean } \\
(\mathrm{SD}) \\
\mathrm{n}=154\end{array}$ & $\begin{array}{c}\text { B } \\
\text { Lower } \\
\text { Achievers } \\
\text { Mean } \\
(\mathrm{SD}) \\
\mathrm{n}=38\end{array}$ & $\begin{array}{c}\text { C } \\
\text { Higher } \\
\text { Achievers } \\
\text { Mean } \\
(\mathrm{SD}) \\
\mathrm{n}=39\end{array}$ & $\begin{array}{c}\text { Diff } \\
\text { B - C }\end{array}$ & df & $t$ & $p$ \\
\hline 1 Learning general science & $\begin{array}{l}3.32 \\
(0.74)\end{array}$ & $\begin{array}{l}3.31 \\
(0.74)\end{array}$ & $\begin{array}{l}3.41 \\
(0.59)\end{array}$ & 0.10 & 75 & 0.62 & .54 \\
\hline 2 Doing your homework without help & $\begin{array}{l}3.31 \\
(0.77)\end{array}$ & $\begin{array}{l}2.95 \\
(0.87)\end{array}$ & $\begin{array}{l}3.59 \\
(0.59)\end{array}$ & 0.64 & 75 & 3.80 & .00 \\
\hline 3 Playing sports & $\begin{array}{l}3.27 \\
(0.93)\end{array}$ & $\begin{array}{l}3.61 \\
(0.79)\end{array}$ & $\begin{array}{l}3.25 \\
(0.82)\end{array}$ & 0.36 & 75 & 1.90 & .06 \\
\hline 4 Handing your homework in on time & $\begin{array}{l}3.20 \\
(0.72)\end{array}$ & $\begin{array}{l}2.95 \\
(0.84)\end{array}$ & $\begin{array}{l}3.31 \\
(0.66)\end{array}$ & 0.64 & 75 & 2.11 & .04 \\
\hline 5 Working in a group & $\begin{array}{l}3.20 \\
(0.80)\end{array}$ & $\begin{array}{l}3.03 \\
(0.97) \\
\end{array}$ & $\begin{array}{l}3.49 \\
(0.64)\end{array}$ & 0.46 & 75 & 2.46 & .16 \\
\hline $\begin{array}{l}6 \text { Producing work that meets teacher's } \\
\text { expectations }\end{array}$ & $\begin{array}{l}3.15 \\
(0.77)\end{array}$ & $\begin{array}{l}2.63 \\
(0.88)\end{array}$ & $\begin{array}{l}3.54 \\
(0.51)\end{array}$ & 0.91 & 75 & 5.51 & .00 \\
\hline 7 Learning a new card game or board game & $\begin{array}{l}3.13 \\
(0.84) \\
\end{array}$ & $\begin{array}{l}3.21 \\
(0.84) \\
\end{array}$ & $\begin{array}{l}3.18 \\
(0.79)\end{array}$ & 0.03 & 75 & 0.17 & .87 \\
\hline $\begin{array}{l}8 \text { Resisting pressure from friends to do } \\
\text { things that could get you into trouble }\end{array}$ & $\begin{array}{l}3.12 \\
(0.83)\end{array}$ & $\begin{array}{l}3.05 \\
(0.90)\end{array}$ & $\begin{array}{l}3.31 \\
(0.77)\end{array}$ & 0.26 & 75 & 1.34 & .18 \\
\hline 9 Learning computer skills & $\begin{array}{l}2.97 \\
(0.89)\end{array}$ & $\begin{array}{l}2.95 \\
(0.93)\end{array}$ & $\begin{array}{l}3.08 \\
(0.77)\end{array}$ & 0.13 & 75 & 0.67 & .51 \\
\hline 10 Talking with a new classmate & $\begin{array}{l}2.97 \\
(0.96) \\
\end{array}$ & $\begin{array}{l}2.92 \\
(0.94)\end{array}$ & $\begin{array}{l}3.08 \\
(0.87)\end{array}$ & 0.16 & 75 & 0.76 & .45 \\
\hline 11 Learning mathematics & $\begin{array}{l}2.93 \\
(0.91)\end{array}$ & $\begin{array}{l}2.53 \\
(0.80)\end{array}$ & $\begin{array}{l}3.38 \\
(0.96)\end{array}$ & 0.85 & 75 & 4.26 & .00 \\
\hline $\begin{array}{l}12 \text { Participating in lessons and class } \\
\text { activities }\end{array}$ & $\begin{array}{l}2.92 \\
(0.86)\end{array}$ & $\begin{array}{l}2.92 \\
(0.85)\end{array}$ & $\begin{array}{l}3.08 \\
(0.93)\end{array}$ & 0.16 & 75 & 0.77 & .45 \\
\hline 13 Solving problems & $\begin{array}{l}2.91 \\
(0.79)\end{array}$ & $\begin{array}{l}2.66 \\
(0.78)\end{array}$ & $\begin{array}{l}3.13 \\
(0.70)\end{array}$ & 0.47 & 75 & 2.79 & .00 \\
\hline 14 Learning Chinese reading skills & $\begin{array}{l}2.84 \\
(0.81)\end{array}$ & $\begin{array}{l}2.42 \\
(0.79)\end{array}$ & $\begin{array}{l}3.18 \\
(0.68)\end{array}$ & 0.76 & 75 & 4.50 & .00 \\
\hline 15 Finding things that get lost & $\begin{array}{l}2.84 \\
(0.86)\end{array}$ & $\begin{array}{l}2.92 \\
(0.91) \\
\end{array}$ & $\begin{array}{l}2.87 \\
(0.86) \\
\end{array}$ & 0.05 & 75 & 0.24 & .81 \\
\hline 16 Controlling your temper & $\begin{array}{l}2.84 \\
(0.90)\end{array}$ & $\begin{array}{l}2.84 \\
(1.05)\end{array}$ & $\begin{array}{l}2.77 \\
(0.90)\end{array}$ & 0.07 & 75 & 0.33 & .75 \\
\hline 17 Helping with housework at home & $\begin{array}{l}2.77 \\
(0.90)\end{array}$ & $\begin{array}{l}2.92 \\
(1.01)\end{array}$ & $\begin{array}{l}2.87 \\
(0.73)\end{array}$ & 0.05 & 75 & 0.28 & .78 \\
\hline 18 Drawing pictures & $\begin{array}{l}2.76 \\
(1.03)\end{array}$ & $\begin{array}{l}2.79 \\
(0.96)\end{array}$ & $\begin{array}{l}2.59 \\
(0.99)\end{array}$ & 0.20 & 75 & 0.90 & .37 \\
\hline 19 Concentrating on your studies & $\begin{array}{l}2.68 \\
(0.84)\end{array}$ & $\begin{array}{l}2.29 \\
(0.87)\end{array}$ & $\begin{array}{l}3.03 \\
(0.84)\end{array}$ & 0.74 & 75 & 3.78 & .00 \\
\hline 20 Learning English conversation skills & $\begin{array}{l}2.63 \\
(0.93)\end{array}$ & $\begin{array}{l}1.97 \\
(0.88)\end{array}$ & $\begin{array}{l}3.05 \\
(0.76)\end{array}$ & 1.08 & 75 & 5.74 & .00 \\
\hline 21 Learning English spelling skills & $\begin{array}{l}2.61 \\
(0.99)\end{array}$ & $\begin{array}{l}1.95 \\
(0.87)\end{array}$ & $\begin{array}{l}3.15 \\
(0.78)\end{array}$ & 1.20 & 75 & 6.42 & .00 \\
\hline $\begin{array}{l}22 \text { Learning Putonghua conversation } \\
\text { skills }\end{array}$ & $\begin{array}{l}2.60 \\
(0.96)\end{array}$ & $\begin{array}{l}2.21 \\
(0.96)\end{array}$ & $\begin{array}{l}2.85 \\
(0.87)\end{array}$ & 0.64 & 75 & 3.03 & .03 \\
\hline 23 Singing a new song & $\begin{array}{l}2.45 \\
(1.04)\end{array}$ & $\begin{array}{l}2.42 \\
(1.00)\end{array}$ & $\begin{array}{l}2.49 \\
(1.08)\end{array}$ & 0.07 & 75 & 0.28 & .78 \\
\hline 24 Learning Chinese writing skills & $\begin{array}{l}2.24 \\
(0.78)\end{array}$ & $\begin{array}{l}2.13 \\
(0.70)\end{array}$ & $\begin{array}{l}2.44 \\
(0.85)\end{array}$ & 0.31 & 75 & 1.71 & .19 \\
\hline
\end{tabular}


degree of worry concerning the health of family members (girls' mean $=3.22$, SD 0.93; boys' mean $=2.87$, SD 1.09; $\mathrm{p}<.03$ ).

When the responses of the younger children (P3) were compared with those of the older students (P6) three significant differences were found. The older students reported significantly more worries concerning their entry to a good secondary school $(\mathrm{P} 6=3.04, \mathrm{SD} 0.89 ; \mathrm{P} 3=2.41$, SD 1.25; $<<.001)$, and were more concerned about their teachers getting a bad impression if work is not handed in on time (P6 $=2.30$, SD1.05; $\mathrm{P} 3=1.79, \mathrm{SD} 1.04 ; \mathrm{p}<.001)$. Younger children recorded a higher degree of worry than older children about their own health $(\mathrm{P} 3=3.18 \mathrm{SD}$ $1.17 ; \mathrm{P} 6=2.60 \mathrm{SD} 1.06 ; \mathrm{p}<.001)$.

Research question 2 invited a comparison between the worries of lower-achieving and higher-achieving children. Table 1 reveals that the two groups differed significantly on 7 of the 20 items in the questionnaire. Indeed, figures in columns B show clearly that in 6 of the items the lower-achieving children registered much higher degrees of worry (above 3.0 on the 4-point rating scale). The most significant differences related to worries concerning school tests and examination results, promotion to a good secondary school, difficulty level of schoolwork, and meeting teachers' expectations, with low achievers expressing the greater degree of worry. In other matters not related to schoolwork, the lower achievers were significantly more worried than higher-achievers about being teased, and about their personal appearance.

Table 2 summarizes the information relating to self-efficacy for the whole sample, and separately for lower-achieving and higher-achieving children. The data provide answers to research questions 3 and 4 . A mean self-rating score above 2.5 can be interpreted as tending toward a positive belief about one's own self-efficacy. A mean rating score below 1.9 can be interpreted as tending to doubt one's self-efficacy. Figures presented in Table 2 column A are in descending order of magnitude.

In Table 2, column A indicates that for the whole sample of children, mean self-efficacy ratings are very positive. Of the 24 items in the SES, 8 (33\%) received ratings above 3.0, suggesting quite strong self-efficacy beliefs in this group of children, particularly in terms of personal reliability in schoolwork, self-management, and in learning science, sports and games. There were no mean ratings below 2.2 on the 4-point scale, and 18 items $(75 \%)$ yielded a mean rating above 2.7 .

When the self-efficacy ratings for lower achievers and higher achievers were compared, 10 significant differences were detected $(\mathrm{p}<.05)$ all showing that higher-achieving children held more positive beliefs about their self-efficacy in relation to personal reliability, self-management in schoolwork, and learning particular subjects such as mathematics, English and Putonghua. In 18 out of the 24 items in SES (75\%) the higher-achievers rated themselves higher in self-efficacy. In particular, Table 2 reveals clearly that lower achievers were less certain than higher-achievers about their ability to learn a second language (English and Putonghua). It is only in non-academic and practical areas such as drawing, board games, sport and helping at home that lower-achievers rate themselves more confidently than the higher achievers.

Finally, data from the whole sample $(n=154)$ were used to determine correlations among the variables of academic achievement (derived from records of children's classroom test results), degree of worry (as reflected in mean scores on the Student Worries Scale), and perceived selfefficacy (as reflected in mean rating scores from the Self-efficacy Scale). Table 3 summarises the results from these Pearson product-moment calculations.

It can be observed that a significant positive association was found between self-efficacy and achievement $(\mathrm{r}=.31)$ suggesting that in this sample of children, there is at least a slight-to-moderate tendency for children with higher self-efficacy to obtain higher academic test results, and vice versa. However, it must be noted that a correlation coefficient of .31 should not be interpreted as reflecting a very powerful association between the two variables. 
Table 3. Intercorrelations among scores for self-efficacy, degree of worry and academic
achievement

\begin{tabular}{|lccc|}
\hline & Achievement & Worry & Self-efficacy \\
\hline Achievement & $\mathbf{1 . 0 0 0}$ & $-\mathbf{3 0 * *}$ & $\begin{array}{c}.31 * * \\
-.34 *\end{array}$ \\
Worry & & $\mathbf{1 . 0 0 0}$ & $\begin{array}{c}\mathbf{1 . 0 0 0} \\
\text { Self-efficacy }\end{array}$ \\
& & & \\
\hline
\end{tabular}

** Correlation coefficient significant at or beyond .01 level (2-tailed).

Significant negative associations were found between self-efficacy and degree of worrying $(r=$ $-.34)$, and between degree of worrying and school achievement $(\mathrm{r}=-.30)$. These findings suggest a slight-to-moderate tendency for children who worry most to obtain poor academic test results (and vice versa) and for children who are weak in self-efficacy to exhibit a greater degree of worrying. Again, the coefficients are not large, and these associations, although statistically significant, cannot be regarded as powerful. It can be concluded that the answer to the question, "Do significant associations exist between primary school children's level of self-efficacy, academic achievement level, and the degree to which they worry?" is that the three variables are associated at a fairly low, but statistically significant, level.

\section{DISCUSSION}

This study has confirmed that primary school children in Hong Kong do worry to a moderate degree about a variety of issues such as the health and employment of family members, their own health, and the fear of getting poor tests results in school. This finding supports data from similar studies in other countries (e.g. Christie \& MacMullan, 1998; Muris et al., 1998; Ollendick, 1983). It also adds important information for the database in Hong Kong, where previous studies have focused only on worries of students of secondary school age (e.g. Hui, 2001; Kong et al., 2006; Li \& Ng, 1992). In particular, this study has demonstrated that worrying about school tests and 'getting good grades' - already identified as typical of older students in Hong Kong - actually begins much earlier, in the primary school years. Whereas students in secondary school, particularly lower achievers, worry about gaining a place in further education and being able to choose a reasonable career path, these primary school children are worrying already about getting into a secondary school of their choice. This study revealed that their degree of worry over such matters increases with age as the students move through the primary school years. Other writers have observed that children's worries change in intensity over time, partly as a result of the children's increasing maturity and partly as a result of new pressures or expectations placed upon them (Borkovec et al., 1991; Vasey \& Daleiden, 1994).

These worries about school matters are quite understandable in the context of Hong Kong where the allocation system for secondary school places very heavy emphasis on good academic achievement in the primary years. Chinese parents are greatly concerned to ensure that their children perform well in school and pass all examinations in order to progress to the next level in education (Ho, 1999). It is not surprising, therefore, to find that parental pressure and high expectations for success in schoolwork, tests and examinations cause children to worry. There is no simple or short-term remedy to this problem at the moment, but longer term it is hoped that reforms currently 
being implemented in curriculum and the assessment methods in Hong Kong schools may reduce the pressure on students. Meanwhile, school counseling services still need to closely monitor the stress levels exhibited by students, particularly when it is close to examination times. It is also advisable to teach all students appropriate coping and self-management strategies for controlling their own workload and stress, and for approaching tests and examinations with effective study methods.

It is clear in the extant research literature from other countries that health issues have also been identified as prime sources of worry for children (e.g. Charlesworth, 2000; Muris et al., 1998; Snipstad et al., 2005). In this study, the children's concerns over health may be explained in part by the fact that the study was completed not very long after the SARS (Sudden Acute Respiratory Syndrome) epidemic had swept through Hong Kong resulting in many deaths, and at a time when much publicity was being given to the possibility of future outbreaks of severe illness caused by the H5N1 avian flu virus. In such a climate of apprehension in the community, children's general awareness of health issues has been greatly heightened. In this study it was found that the younger children displayed the greatest degree of worry over their health. It is important that educators, counsellors and others charged with the duty of providing children with information on disease prevention, health and hygiene do so in a positive and reassuring manner so as to avoid causing children excessive worry and anxiety.

In terms of a possible need for counselling or emotional support, it is important to note from the standard deviations recorded in Table 1 that (assuming normality in the distribution of scores) approximately 24 children (16\% of the group) would have registered scores above $+1 \mathrm{SD}$, thus representing a rating score well above 3 in many items in the questionnaire. Scores above 3 on a 4point rating scale indicate a higher degree of worry for these individuals than the mean score for the whole group suggests. For these children, excessive worrying could be detrimental both to quality of life and to academic progress (McGuigan, 1999). Schools need to be alert to the fact that a few children may worry excessively and may require supportive counselling to help them deal with their immediate worries and anxieties. In such matters, close and trusting communication between school and parents is essential for early identification of children's problems and for ongoing consistent support. Support of this type is particularly relevant for lower-achieving students who, as this study shows, are naturally more prone to worry excessively about issues such as tests, examinations, difficulty of schoolwork, and meeting teachers' expectations. These students particularly would benefit from guidance and counselling to help them deal with their worries about teasing from other children. Hopefully, schools are working towards creating a more socially inclusive environment where teasing among peers is a very rare occurrence.

It is reassuring to find that the average selfefficacy ratings among this sample of children were very positive across a broad range of competencies. The majority of children felt confident in their personal reliability, selfmanagement, and ability to learn science, sports and games. However, in $75 \%$ of the items in SES, higher achievers gave themselves a more positive rating that did lower achievers. The significant differences between lower-achieving and higherachieving children in several areas of perceived selfefficacy are important to note; they suggest a possible reciprocal relationship between success in school and the development of positive perceptions of self-efficacy (Schunk \& Pajares, 2002).

Data in Table 3 indicate that there is indeed an association between achievement and self-efficacy $(\mathrm{r}=.31)$, although not a powerful relationship. In all items in the $S E S$ relating to schoolwork, assessment, and meeting teachers' expectations the lower-achieving students were somewhat less confident than higher achievers, probably because of prior experience of the negative repercussions arising from poor results. As Bandura (1997) points out, learners who experience satisfying 
outcomes from their efforts develop positive beliefs about their own capability. Such beliefs are further strengthened by praise and encouragement from teachers and parents, thus having a powerful effect on motivation. Conversely, learners who constantly experience failure are likely to lose confidence in their own ability, resulting in lowered motivation (Westwood, 2004). The message for teachers would seem to be that the schoolwork set for children should be placed at a level where they stand a good chance of being successful rather than unsuccessful. In addition, children need to be taught to use effective learning strategies when tackling particular tasks to make them feel that they have control over their efforts and the results (Deshler 2005; Lerner \& Kline, 2006). For some students, the use of 'attribution retraining' techniques may be helpful because these are designed to show learners very clearly how the effort they put into a task significantly influences the quality of the outcome (Cole \& Chan, 1990).

It was hypothesized that an association would be found not only between self-efficacy and achievement, but also between self-efficacy and degree of worrying. An inverse relationship was discovered between these variables $(r=-.34)$, supporting the notion that there is a slight tendency for learners who worry most to be those who also have weaker beliefs about their own efficacy in a variety of contexts, and vice versa. It is impossible to say whether helping a child feel more competent, using methods such as those described above, would result directly in a reduction of worrying - but the possibility is attractive. Future experimental studies could examine this issue in more detail.

Finally, it was found that degree of worrying was negatively correlated $(r=-.30)$ with achievement, suggesting that there is a slight tendency for children who worry most to have poorer academic achievement than those who worry least. However, in this study only 10 percent of the variance in achievement could be accounted for by children's degree of worrying.

\section{LIMITATIONS AND FUTURE RESEARCH}

Several limitations must be acknowledged in this study. First, although the sample of students was reasonably large $(n=154)$ it was taken from only one school. Further research would be necessary across several primary schools to confirm the findings reported here.

Second, the study concerned itself only with the intensity of worrying, not the frequency (i.e. how often children engaged in worrying thoughts). It is possible that worrying about examinations and promotion to higher classes for example occurs intensely at only a certain time each year, while worries about family matters or health might be more ongoing. Studies in the future could address the 'frequency' issue, and could attempt to discover any 'seasonal' influences on children's patterns of worrying.

Third, although the internal consistency of the two instruments used in this study is acceptably high, there is currently no information to confirm their validity. The Student Worries Scale might claim to have good content validity because the items were derived from the self-reported worries identified by the children themselves in the focus groups, but no hard evidence is available at this time to confirm other aspects of its suitability for purpose. Similarly, although the self-efficacy scale $(S E S)$ has reasonable face validity and was adapted from an existing instrument of proven reliability and validity (Yuen et al., 2006), there is no direct evidence yet to confirm its concurrent validity. Future research might explore in more detail the construct and psychometric characteristics of this adaptation of the ANASS, and might compare the results from the $S E S$ with other scales purporting to assess self-efficacy.

\section{REFERENCES}

Bandura, A. (1997). Self-efficacy: The exercise of control. New York: Freeman.

Bandura, A. (1999). Self-efficacy: Toward a unifying theory of behavioral change. In 
R.F.Baumeister (Ed.), The 'self' in social psychology (pp.285-298). Philadelphia, PA: Psychology Press.

Barlow, D.H. (1991). The nature of anxiety: Anxiety, depression and emotional disorders. In R.M.Rapee \& D.H.Barlow (Eds.), Chronic anxiety: Generalized anxiety disorder and mixed-anxiety-depression (pp.1-28). New York: Guilford Press.

Borkovec, T.D., Shadick, R.N. \& Hopkins, M. (1991). The nature of normal and pathological worry. In R.M.Rapee \& D.H.Barlow (Eds.), Chronic anxiety: Generalized anxiety disorder and mixed-anxiety-depression (pp.29-51). New York: Guilford Press.

Brimacombe, M. (1985). What children worry about. New Society, 73,(1181), 223-225.

Charlesworth, R. (2000). Understanding child development. Albany, NY: Delmar.

Christie, E. \& Macmullin, C. (1998). What do children worry about? Australian Journal of Guidance and Counselling, 8,(1), 9-24.

Cole, P. \& Chan, L. (1990). Methods and strategies for special education. New York: Prentice Hall.

DeCatanzaro, D.A. (1999). Motivation and emotion. Upper Saddle River, NJ: Prentice Hall.

Deshler, D.D. (2005). Adolescents with learning disabilities: Unique challenges and reasons for hope. Learning Disability Quarterly, 28(2), 22-24.

Ho, M.K.W. (1999). Being female in Hong Kong: The experience of mothers and daughters. Unpublished $\mathrm{PhD}$ dissertation, University of Bristol England

Hui, E.K.P. (2001). Hong Kong students' and teachers' beliefs on students' concerns and their causal explanation. Educational Research, 43 (3), 279-284.

Klinger, E. (1999). Thought flow: Properties and mechanisms underlying shifts in content. In J.A.Singer \& P.Salovey (Eds.), At play in the fields of consciousness (pp.29-50). Mahwah, NJ: Erlbaum.

Kong, L.S.Y., Westwood, P. \& Yuen, M.T. (2006). School-related worries of adolescents in Hong
Kong: A single school study. Hong Kong Special Education Forum, 8, 21-41.

Lerner, J. \& Kline, F. (2006). Learning disabilities and related disorders (10th ed.). Boston: Houghton Mifflin.

Li, S.F. \& Ng, R.N.K. (1992). Life stressors and help-seeking behaviour of secondary school students in Kwun Tong: A comparative study of students' and their teachers' perceptions. Hong Kong: Kwun Tong District Committee on Promotion of Mental Health Education.

McGuigan, F.J. (1999). Encyclopedia of stress. Boston: Allyn \& Bacon.

Maddux, J.E. \& Gosselin, J.T. (2003). Selfefficacy. In M.R.Leary \& J.P.Tangney (Eds.), Handbook of self-identity (pp.213-238). New York: Guilford Press.

Mathews, A. (1990). Why worry? The cognitive function of anxiety. Behaviour Research and Therapy, 28(6), 455-468.

Muris, P., Meesters, C., Merckelbach, H., Sermon, A. \& Zwakhalen, S. (1998). Worry in normal children. Journal of the American Academy of Child and Adolescent Psychiatry, 37(7), 703-710.

Ollendick, T.H. (1983). Reliability and validity of the revised Fear Survey Schedule for Children (FSSC-R). Behaviour Research and Therapy, 21(6), 685-692.

Rapee, R.M. (1991). Psychological factors involved in generalized anxiety. In R.M.Rapee \& D.H.Barlow (Eds.), Chronic anxiety: Generalized anxiety disorder and mixedanxiety-depression (pp. 76-94). New York: Guilford Press.

Roemer, L. \& Borkovec, T.D. (1993). Worry: Unwanted cognitive activity that controls unwanted somatic experiences. In D.M.Wegner \& J.W.Pennebaker (Eds.), Handbook of mental control (pp.220-238). Englewood Cliffs, NJ: Prentice Hall.

Sarason, S.B., Davidson, K.S., Lighthall, F.F., Waite, R.R., \& Ruebush, B.K. (1960). Anxiety in elementary school children. New York: Wiley.

Schunk, D.H. \& Pajares, F. (2002). The development of academic self-efficacy. In 
A.Wingfield \& J.S.Eccles (Eds.), Development of achievement motivation (pp.15-31). San Diego: Academic Press.

Silverman, W.K., La Greca, A.M. \& Wasserstein, S. (1995). What do children worry about? Worries and their relation to anxiety. Child Development, 66, 671-686.

Simon, A. \& Ward, L.O. (1974). Variables influencing the sources, frequency and intensity of worry in secondary school pupils. British Journal of Social and Clinical Psychology, 13, 391-396.

Smith, E.V., Wakely, M.B., De Kruif, R.E.L. \& Swartz, C.W. (2003). Optimizing rating scales for self-efficacy and other research. Educational and Psychological Measurement, 63( 3), 369-391.

Snipstad, M.B., Lie, G.T. \& Winje, D. (2005). What do Tanzanian children worry about? African Journal of AIDS Research, 4( 3), 183193.

Vasey, M.W. \& Daleiden, E.L. (1994). Worry in children. In G.C.L.Davey \& F.Tallis (Eds).
Worrying: Perspectives on theory, assessment and treatment (pp.185-207). Chichester, England: Wiley.

Westwood, P.S. (2004). Affective factors in learning difficulties. In B.A.Knight \& W.Scott (Eds.), Learning difficulties: Multiple perspectives (pp.187-202). Sydney: Pearson Educational.

Winkley, L. (1996). Emotional problems in children and young people. London: Cassell.

Woolcock, E. \& Campbell, M.A. (2005). The role of teachers in the support of students with obsessive-compulsive disorder. Australian Educational and Developmental Psychologist, 22 (1), 54-64.

Yuen, MT., Westwood, P. \& Wong, G. (in press). Self-efficacy perceptions of Chinese primaryage students with specific learning difficulties: A perspective from Hong Kong. International Journal of Special Education.

Zeligs, R. (1939). Children's worries. Sociology and Social Research, 24, 22-32. 